\title{
Serum levels of immune globulins in postmaturity
}

\author{
C. PAPADATOS, D. Alexiou, G. PAPAEVANGELOU, H. PETROPOULOS, and J. MENDRIS \\ From the Neonatal Department of Alexandra Maternity Hospital, and the Department of Hygiene and \\ Epidemiology, University of Athens, Greece
}

\begin{abstract}
Papadatos, C., Alexiou, D., Papaevangelou, G., Petropoulos, H., and Mendris, J. (1974). Archives of Disease in Childhood, 49, 222. Serum levels of immune globulins in postmaturity. Immunoglobulins $G, A$, and $M$ were measured in the serum of 32 term and 59 postmature newborns and their respective mothers. Duration of pregnancy was judged by calculated gestational age, placental pathological findings, and clinically recognizable signs of postmaturity.

IgA levels were higher and IgG levels were lower in postmature babies and their respective mothers than in term newborns and their mothers. IgM levels were similar in the two groups studied.
\end{abstract}

Immunoglobulin studies in postmaturity are few and contradictory. Ackerman, Taylor, and O'Loughlin (1969) found raised concentrations of IgA and IgG at birth, but this was not noted in other investigations (Yeung and Hobbs, 1968; Papadatos et al., 1969).

This study was undertaken to examine further whether any significant changes in immunoglobulin concentrations do occur in maternal and fetal serum of prolonged pregnancies.

\section{Material and methods}

Of 91 newborns studied, 32 were term (37-41 weeks) unselected babies with a normal pregnancy and delivery, and 59 were consecutive postmature infants born after a gestation of $\mathbf{4 2}$ or more completed weeks.

In order to minimize errors in estimating the duration of pregnancy, classification of our material was made blindly in relation to three criteria. (a) Gestational age, as calculated from the first day of the last menstrual period. (b) Occurrence of the characteristic histopatho-

Received 3 September 1973. logical placental abnormalities encountered in postmaturity, namely, small or extensive perivascular necroses with calcium deposits, severe vascular congestion, and/or thrombosis, with intermediate sclerosis and limited or extensive placental infarcts. (c) Presence of the recognized clinical signs of postmaturity. Data of this classification are shown in Table I.

Blood samples were obtained from the umbilical cord of all neonates and from the mother by venepuncture within the first 24 hours after birth. All sera were maintained after separation at $-20^{\circ} \mathrm{C}$.

We used the quantitative gel diffusion technique with antibody incorporated into the agar in appropriate dilutions as described by Mancini, Carbonara, and Heremans (1966). Immunoglobulin levels were determined in two large batches with the same immunoplates and serum reference standards (Hyland Laboratories, Los Angeles, Calif., U.S.A.).

Student's ' $t$ ' test was used for the estimation of the difference between two mean values.

\section{Results}

As seen in Table $I$ there is an almost complete agreement (concordance rate $96 \cdot 7 \%$ ) in the

TABLE I

Distribution of cases according to gestational age, placental pathology, and clinical signs of postmaturity

\begin{tabular}{|c|c|c|c|c|c|}
\hline \multirow{2}{*}{$\begin{array}{l}\text { Duration of pregnancy } \\
\text { (wk) }\end{array}$} & \multirow{2}{*}{ No. of cases } & \multicolumn{2}{|c|}{ Placental pathology } & \multicolumn{2}{|c|}{ Clinical signs of postmaturity } \\
\hline & & Absent & Present & Absent & Present \\
\hline $\begin{array}{l}<42 \\
>42\end{array}$ & $\begin{array}{l}32 \\
59\end{array}$ & $\begin{array}{r}31 \\
2\end{array}$ & $\begin{array}{r}1 \\
57\end{array}$ & $\begin{array}{r}32 \\
9\end{array}$ & $\begin{array}{r}0 \\
50\end{array}$ \\
\hline Total & 91 & 33 & 58 & 41 & 50 \\
\hline
\end{tabular}


TABLE II

Concentrations or presence of $\operatorname{IgG}, \operatorname{Ig} A$, and $\operatorname{IgM}$ in maternal and cord blood in cases with gestational age greater or less than 42 weeks

\begin{tabular}{|c|c|c|c|c|c|c|c|}
\hline \multirow{2}{*}{$\begin{array}{l}\text { Duration of pregnancy } \\
(\mathrm{wk})\end{array}$} & \multirow{2}{*}{$\begin{array}{l}\text { No. of } \\
\text { cases }\end{array}$} & \multicolumn{2}{|c|}{ 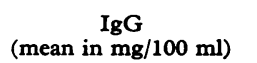 } & \multicolumn{2}{|c|}{$\frac{\mathrm{IgM}}{(\text { mean in } \mathrm{mg} / 100 \mathrm{ml} \text { ) }}$} & \multicolumn{2}{|l|}{ IgA } \\
\hline & & Mother & Newborn & Mother & Newborn & $\begin{array}{c}\text { Mother } \\
\text { (mean in } \mathrm{mg} / 100 \mathrm{ml} \text { ) }\end{array}$ & $\begin{array}{l}\text { Newborn } \\
\text { (\% present) }\end{array}$ \\
\hline $\begin{array}{l}<42 \\
>42\end{array}$ & $\begin{array}{l}32 \\
59\end{array}$ & $\begin{array}{l}929 \cdot 4 \\
829 \cdot 7\end{array}$ & $\begin{array}{r}1004 \cdot 7 \\
745 \cdot 6\end{array}$ & $\begin{array}{l}118 \cdot 4 \\
123 \cdot 1\end{array}$ & $\begin{array}{l}21 \cdot 3 \\
16 \cdot 8\end{array}$ & $\begin{array}{l}193 \cdot 3 \\
280 \cdot 7\end{array}$ & $\begin{array}{r}9 \\
32\end{array}$ \\
\hline
\end{tabular}

classification of term and postmature newborns on the basis of placental pathological findings or duration of pregnancy. In contrast, clinical signs of postmaturity are a slightly less sensitive indicator of postmaturity. Thus they are not noted in 9 out of the 59 newborns characterized on the basis of duration of pregnancy as postmature. The 50 newborns with clinical signs of postmaturity should be considered as more severely postmature and are compared with the 31 who have no evidence of postmaturity at all.

IgG. There was a significant decrease of maternal IgG levels in a prolongation of pregnancy to 42 weeks or more $(P<0.05)$. Thus, mean IgG values in mothers of term babies were $929.4 \mathrm{mg} /$ $100 \mathrm{ml}$, while in postmaturity mean maternal levels dropped to $829.7 \mathrm{mg} / 100 \mathrm{ml}$. This IgG decrease is even more marked in the neonate $(1004.7 \mathrm{mg} /$ $100 \mathrm{ml}$ in the term against mean levels of $745.6 \mathrm{mg} /$ $100 \mathrm{ml}$ in the postmature) (Table II).

Table III shows that both maternal and neonatal IgG levels were significantly lower when duration of pregnancy was judged according to the presence or absence of any recognizable sign of postmaturity. Thus, mean maternal IgG values were $914 \mathrm{mg} / 100$ $\mathrm{ml}$ against $835 \mathrm{mg} / 100 \mathrm{ml}$ when all signs of postmaturity were present. As shown in Table III, neonatal levels decreased conspicuously in the newborn with all the signs of postmaturity. The differences are significant $(P<0.01)$. The decrease in the neonate was more pronounced than that seen in maternal serum.

There is, furthermore, a significant $(P<0.05)$ correlation between mother and newborn as far as IgG levels are concerned in term and in prolonged pregnancies, regardless of whether postmaturity is defined on the basis of duration of pregnancy, placental findings, or clinically recognizable signs of a prolonged pregnancy.

IgM. There is no change in IgM maternal and neonatal levels if duration of pregnancy, placental findings, or obviously present signs of postmaturity are taken into consideration. Tables II and III show differences, which are not significant $(P<0 \cdot 1)$. There is no correlation $(P<0.05)$ between the IgM levels of mother and newborn in term or prolonged pregnancies.

IgA. Maternal IgA levels increase in prolonged pregnancies. Thus, mean maternal levels in term pregnancies were $193.3 \mathrm{mg} / 100 \mathrm{ml}$ against $280 \cdot 7$ $\mathrm{mg} / 100 \mathrm{ml}$ in cases with a prolonged gestation. This increase is significant $(P<0 \cdot 01)$. The same IgA relation is noted in pregnancies without or with all signs of postmaturity (Table III). Thus, mean values in the absence of any signs of postmaturity were $181 \cdot 2 \mathrm{mg} / 100 \mathrm{ml}$ against $285.9 \mathrm{mg} / 100 \mathrm{ml}$ in

TABLE III

Concentrations or presence of $\operatorname{IgG}, \operatorname{Ig} A$, and $\operatorname{IgM}$ in maternal and cord blood in cases without or with all signs (clinical, pathology, gestational age) of postmaturity

\begin{tabular}{|c|c|c|c|c|c|c|c|}
\hline \multirow{2}{*}{ Postmaturity } & \multirow{2}{*}{$\begin{array}{l}\text { No. of } \\
\text { cases }\end{array}$} & \multicolumn{2}{|c|}{$c=\frac{\mathrm{IgG}}{(\text { mean in } \mathrm{mg} / 100 \mathrm{ml} \text { ) }}$} & \multicolumn{2}{|c|}{$\begin{array}{c}\text { IgM } \\
(\text { mean in } \mathrm{mg} / 100 \mathrm{ml} \text { ) }\end{array}$} & \multicolumn{2}{|l|}{ IgA } \\
\hline & & Mother & Newborn & Mother & Newborn & $\begin{array}{c}\text { Mother } \\
\text { (mean in } \mathrm{mg} / 100 \mathrm{ml} \text { ) }\end{array}$ & $\begin{array}{l}\text { Newborn } \\
\text { (\% present) }\end{array}$ \\
\hline $\begin{array}{l}\text { No signs } \\
\text { All signs }\end{array}$ & $\begin{array}{l}31 \\
50\end{array}$ & $\begin{array}{l}914 \cdot 0 \\
835 \cdot 0\end{array}$ & $\begin{array}{r}1010 \cdot 2 \\
745 \cdot 8\end{array}$ & $\begin{array}{l}103 \cdot 2 \\
129 \cdot 1\end{array}$ & $\begin{array}{l}19 \cdot 1 \\
17 \cdot 7\end{array}$ & $\begin{array}{l}181 \cdot 2 \\
285 \cdot 9\end{array}$ & $\begin{array}{l}10 \\
36\end{array}$ \\
\hline
\end{tabular}


mothers whose babies had obvious clinical signs of postmaturity.

In the term neonate IgA was detectable in the cord blood of only 3 babies ( $9 \%$ ): with a gestational age of more than 42 weeks it was detectable in $32 \%$. The same significant increase of $\operatorname{IgA}(P<0.05)$ is noted if postmaturity is judged on the basis of presence or absence of any of the signs of postmaturity (Table III, last column).

\section{Discussion}

Our data confirm that maternal IgG levels are depressed in postmaturity in comparison with the levels in mothers who deliver term babies. On the other hand, IgA values increase, while IgM remains practically unchanged.

The decrease in the concentration of maternal IgG which has also been described with the normal advancement of pregnancy (Studd, 1971; Maroulis, Buckley, and Younger, 1971) may be primarily an effect of haemodilution, which has been shown to cause hypoalbuminaemia in advanced pregnancy. It would be expected, however, that through this mechanism a similar depression in serum levels of IgA and IgM would occur. We found, however, an increase of IgA, while IgM levels remained unchanged.

Obviously one could postulate also that an altered metabolic regulatory mechanism for control of IgG concentrations in postmaturity must be considered in seeking an explanation for the observed decrease in IgG levels. While the metabolic rate of IgG in postmaturity has not been studied in man, it is well known that the rate of catabolism of this immunoglobulin increases conspicuously in pregnant experimental animals (Jordan and Morgan, 1967). A similar mechanism possibly occurs in humans.

Neonatal values of IgG show a greater decrease in postmature babies than levels encountered in maternal serum. This could result from inhibition of transfer of IgG to the fetus through a damaged placenta.

The mechanism of increase of IgA in the mother is not readily apparent. The presence, however, of increased amounts of IgA in the cord blood could be due to a defective placenta permitting maternal IgA to leak across. This assumption would be supported if IgA were not detectable on heel prick specimens at the age of one week.

\section{REFERENCES}

Ackerman, B. D., Taylor, W. F., and O'Loughlin, B. J. (1969). Serum immunoglobulin levels in postmature infants. Pediatrics, 43, 956.

Jordan, S. M., and Morgan, E. H. (1967). Plasma protein synthesis by tissue slices from pregnant and lactating rats. Biochimica et Biophysica Acta, 174, 373.

Mancini, G., Carbonara, A. O., and Heremans, J. F. (1965). Immunochemical quantitation of antigens by single radial immunodiffusion. Immunochemistry, 2, 235.

Maroulis, G. B., Buckley, R. H., and Younger, J. B. (1971). Serum immunoglobulin concentrations during normal pregnancy. American fournal of Obstetrics and Gynecology, 109, 971.

Papadatos, C., Papaevangelou, G., Alexiou, D., and Mendris, J. (1969). Immunoglobulin levels and gestational age. Biologia Neonatorum, 14, 365.

Studd, J. W. W. (1971). Immunoglobulins in normal pregnancy, pre-eclampsia and pregnancy complicated by the nephrotic syndrome. Fournal of Obstetrics and Gynaecology of the British Commonwealth, 78, 786.

Yeung, C. Y., and Hobbs, J. R. (1968). Serum $\gamma$ G-globulin levels in normal, premature, postmature and small-for-dates newborn babies. Lancet, 1, 1167.

Correspondence to Dr. C. Papadatos, Children's Hospital 'Aglaia Kyriakou', Goudi, Athens, Greece. 